\title{
DNA barcoding and traditional taxonomy unified through Integrative Taxonomy: a view that challenges the debate questioning both methodologies
}

\author{
Amanda Ciprandi Pires ${ }^{1,2}$ \& Luciane Marinoni ${ }^{1}$ \\ ${ }^{1}$ Programa de Pós-graduação em Entomologia, Departamento de Zoologia, \\ Universidade Federal do Paraná - UFPR, \\ CP 19020, CEP 81531-980, Curitiba, PR, Brasil,e-mail: Imarinoni@ufpr.br \\ ${ }^{2}$ Corresponding author: Amanda Ciprandi Pires, e-mail: amandaciprandi@yahoo.com.br
}

PIRES, A.C. \& MARINONI, L. DNA barcoding and traditional taxonomy unified through Integrative Taxonomy: a view that challenges the debate questioning both methodologies. Biota Neotrop. 10(2): http:// www.biotaneotropica.org.br/v10n2/en/abstract?thematic-review+bn03110022010.

\begin{abstract}
The taxonomic crisis, emphasized in recent years, is marked by the lack of popularity (lack of interest in taxonomy) and financial incentives to study biodiversity. This situation, coupled with the issues involved with the necessity of knowing many yet undiscovered species, has meant that new technologies, including the use of DNA, have emerged to revitalize taxonomy. Part of the scientific community, however, has rejected the use of these innovative ideas. DNA barcoding has especially been the target of numerous criticisms regarding its application, as opposed to the use of morphology. This paper aims to highlight the inconsistency of the debate involving DNA versus morphology, since there is a proposal for the integration of traditional taxonomy and DNA barcoding - the integrative taxonomy. The positive and negative points of this proposal will be discussed, as well as its validity and application. From it, the importance of morphology is recognized and the revitalization of traditional taxonomy is achieved by the addition of technologies to overcome the taxonomic impediment.

Keywords: biodiversity, COI, species, taxonomic impediment, morphology.
\end{abstract}

PIRES, A.C. \& MARINONI, L. União entre DNA barcoding e taxonomia tradicional através da Taxonomia Integrativa: uma visão que contesta o debate questionando uma ou outra metodologia. Biota Neotrop 10(2): http://www.biotaneotropica.org.br/v10n2/pt/abstract?thematic-review+bn03110022010.

Resumo: A crise taxonômica, em destaque nos últimos anos, é marcada pela falta de popularidade (desinteresse pela formação taxonômica) e incentivos financeiros direcionados ao estudo da biodiversidade. Esta situação somada às questões envolvidas com a necessidade de se conhecer as inúmeras espécies ainda desconhecidas tem feito com que novas tecnologias, dentre elas o uso do DNA, tenham surgido como propostas para revitalização da taxonomia. Uma parte da comunidade científica, entretanto, tem rejeitado o uso dessas idéias inovadoras. O DNA barcoding, principalmente, tem sido alvo de inúmeras críticas quanto à sua aplicação em contraposição ao uso da morfologia. O presente artigo visa destacar a inconsistência do debate DNA versus morfologia, pela existência de uma proposta que corresponde à união entre a taxonomia tradicional e o DNA barcoding - a taxonomia integrativa. Os pontos favoráveis e desfavoráveis dessa proposta serão discutidos assim como a sua validade e aplicação. Com ela, a importância da morfologia é reconhecida e ao mesmo tempo tem-se a revitalização da taxonomia tradicional pela aderência das tecnologias incitadas para transposição do impedimento taxonômico.

Palavras-chave: biodiversidade, COI, espécie, impedimento taxonômico, morfologia. 


\section{Introduction}

Taxonomy, the science dedicated to discovering, describing, naming, and identifying species and other taxa, has been the subject of many debates (Lee 2002, Blaxter \& Floyd 2003, Lipscomb et al. 2003, Moritiz \& Cicero 2004, Prendini 2005, Meier et al. 2006, Carvalho et al. 2008) that center on the use of revolutionary ideas (Godfray 2002, Hebert et al. 2003, Tautz et al. 2003) that can help it overcome the "taxonomic crisis" of the last decades (Wilson 1985). This crisis is mainly characterized by a lack of specialists in several groups and geographic areas, and by insufficient funding for taxonomic work (Godfray 2002, Mallet \& Willmott 2003).

As a means to revitalize traditional taxonomy and help it rise above the taxonomic crisis, alternative and complementary approaches have been promoted, for example; molecular taxonomy (Tautz et al. 2003, Hebert et al. 2003), information technology, the development of investment funds (Wheeler 2007) and increased utilization of cybertools (Pyle et al. 2008, La Salle et al. 2009). Among those proposals, DNA barcoding (Hebert et al. 2003) has been particularly successful in the identification and delimitation of new species from various groups (Hebert et al. 2004, Ward et al. 2005, Cywinska et al. 2006, Hajibabaei et al. 2006a, b, Smith et al. 2007, Borisenko et al. 2008, Kerr et al. 2009). This method has received increased acceptance because it is simple and affordable (Padial \& De La Riva 2007).

In spite of the wide acceptance of DNA-based methods, however, a large portion of the taxonomic community has rejected them, fearing that they will deviate funds and incentives from, and represent a threat to traditional morphology (Dunn 2003, Ebach \& Holdrege 2005a, Gregory 2005, Savolainen et al. 2005, Cameron et al. 2006).

In this context, the discussion that follows seeks to emphasize an already existing proposal to integrate traditional taxonomy and DNA barcoding (among other approaches), the integrative taxonomy (Dayrat 2005). This proposal aims to combine different sources of data to recognize and delimitate species. In this view, any information that contributes to such goal is considered as an aid to taxonomy. Thus, within the context of integrative taxonomy, debates questioning this or that methodology become pointless.

First we will discuss the proposal to use DNA data to overcome the taxonomic crisis. Following that, we will raise the issue of "morphology versus DNA". Then, we will discuss the collaboration between DNA barcoding and traditional taxonomy within the context of an integrative taxonomy. The validity of this approach and recent applications will be emphasized. We are aware that Integrative Taxonomy, as originally proposed by Dayrat (2005), has been defined as the science that aims to delimit the units of life's diversity from several multiple and complementary perspectives (phylogeography, comparative morphology, population genetics, ecology, development, behavior etc). However, in the present review we will focus on the integration DNA and morphology and how this approach can be used to solve taxonomic problems that result from the isolated use of either source of information.

\section{Revitalizing Taxonomy Through DNA Barcoding}

The description and identification of species are fundamental to biology. Without taxonomy, biologists in various disciplines would be unable to report their empirical findings or to access available information on their target organisms because they would not be sure of their identities. Taxonomy lays the foundations for the construction of the tree of life, makes baseline data available for conservation and ecology studies, and affords humans the possibility to take advantage of the underutilized resources offered by the earths' biodiversity (Wilson 2004). Despite its importance as a foundation for other disciplines, taxonomy is one of the most neglected fields of research, suffering from low financial investment from fomenting agencies and, probably as a reflex of this, low interest from biology students (Godfray 2002, Wilson 2003).

Two and a half centuries after Linnaeus, there are between 1.5 to 1.8 millions of described species, with an estimate that between five and 100 million species await discovery and description (Wilson 2003). For this reason, the advent of new approaches to stimulate and advance taxonomy, both in terms of investment and popularity, were inevitable (Godfray 2002, Hebert et al. 2003, Tautz et al. 2003, Wheeler 2007, La Salle et al. 2009).

DNA methods aiming to modernize taxonomy were then proposed. Hebert et al. (2003) incited the study of molecular diversity as a means to recognize and identify organisms by bringing up the inherent limitations of morphology, and the steady decrease in the number of specialists available for the task of uncovering our yet unknown diversity. The following limitations of morphology-based taxonomy were mentioned by them:

- Phenotypic plasticity in the characters employed for species recognition lead to incorrect identifications;

- Morphologically cryptic species are often overlooked;

- There is a lack of taxonomic keys to identify immature specimens of many species; and

- Traditional taxonomy requires high levels of expertise in any given group and is therefore restricted to specialists.

According to those authors, because DNA sequences are unique for each species, they can be viewed as genetic 'barcodes' and have the potential to solve the problems inherent to the kind of taxonomy practiced so far. With a possible nucleotide variation of four nitrogenous bases (A, T, C, G) at each site, there are 4 n (where " $n$ " corresponds to the number of nucleotides surveyed) possible codes for any given sequence, making it possible to identify every taxon. The survey of just 15 nucleotide positions can identify 1 billion $\left(4^{15}\right)$ species. The identifications can be performed quickly and at low cost, without the need of a taxonomist in the group. Additional advantages of the method would be the possibility of identifying individuals at any stage of development, and the prospect of discriminating between morphologically identical species.

DNA barcoding is a taxonomic system structured on sequence information from a short stretch of a core DNA sequence. A region of approximately 648-pb of the mitochondrial gene cytochrome c oxidase I (COI) was initially proposed as the barcode source to identify and delimit all animal species (CBOL, Consortium for the Barcode of Life, available at http://www.barcoding.si.edu/ DNABarCoding.htm). The methodology involves the sequencing of that portion of DNA, followed by a comparison with other sequences previously deposited in a database. Species are identified by matching the obtained sequence with sequences of known identity already in the database (Hebert et al. 2003).

The COI was chosen for animal barcoding because of the following advantageous characteristics: First, as in other mitochondrial proteincoding genes, indels (insertions/deletions) are rare, since most lead to a shift in the reading frame (and consequent elimination from the population). Second, universal primers for COI are very robust, enabling the sequencing of representatives of most, if not all, animal phyla. Lastly, COI appears to possess a great range of phylogenetic signal, showing fast rates of nucleotide substitution that not only enable the discrimination of cryptic species, but also can reveal phylogeographic structures within a species (Hebert et al. 2003).

The COI of plants and fungi, on the other hand, is not suitable for DNA barcoding. Like other mitochondrial genes in these groups, it evolves too slowly for species-level discriminations (Chase \& Fay 2010). For this reason, alternative stretches of DNA have been 
proposed as target sequences for the barcoding of these organisms. Two regions of the plastidial DNA have been recommended for terrestrial plants: $m a t K$ and $r b c L$ (CBOL Plant Working Group 2009). For fungi, the internal transcribed spacer (ITS) region of the ribosomal DNA has afforded the best results (Chase \& Fay 2010). Given the fact that a massive amount of literature on the subject refers to the animal kingdom, we will focus the remaining of our discussion on the uses of barcoding in animal taxonomy.

Researchers studying microorganisms were the first to practice a genomic-mediated taxonomy (Pace 1997, Patel et al. 2000, Hebert et al. 2003), long before Hebert et al. (2003). In fact, molecular tools cannot be considered as an innovation to taxonomy, since they have already been used to identify and distinguish between species for a few decades (Sperling et al. 1994). The use of DNA probes (a single-stranded DNA molecule used to detect the presence of a complementary sequence), for exemple, dates back over 30 years, when it was used in the identification and phylogeny of eubacteria and archeobacteria (Fox et al. 1980, Vogler \& Monafhan 2007). In this context, DNA barcoding can be seen as an attempt to revolutionize the study of biodiversity, and has proven to be a powerful tool in the identification of various species.

The idea of identifying and being able to distinguish between species using a short DNA sequence has captured the imagination of many taxonomists, geneticists and researchers involved in biodiversity studies. On April 2004, The Consortium for the Barcode of Life (CBOL) was formed with the help of a concession from the Sloan Foundation, a philanthropic entity created by General Motors. Today, the CBOL involves cooperation between 170 organizations worldwide. The organization aims to explore and develop the barcode as global standard for species identification (available at http://www. barcoding.si.edu/).

The wide acceptance of the barcode of life reflects its scientific success since it was first proposed (Hebert et al. 2004, Ward et al. 2005, Cywinska et al. 2006, Hajibabaei et al. 2006a, Smith et al. 2007, Borisenko et al. 2008, Kerr et al. 2009). Besides having attracted large sums of money, DNA barcoding research has been facilitated by the Barcode of Life Data System (BOLD), an online resource available to the scientific community (http://www.boldsystems.org/views/login. php\#). This resource offers tools that allow researchers to perform neighbor-joining clustering, to store information on the different groups studied, and to identify taxa using an updated sequence library, among other things.

In 2003, Tautz et al. (2003) published an article arguing for the need of a DNA-based taxonomy. The authors defended that the recent genomic revolution had laid the foundations for the development of a universal taxonomic system centered on DNA data. They proposed to substitute the existing classification with a system in which a small portion of the genome is sequenced and used both for species classification and identification. In this way, DNA sequences would become part of the type-material. Such a system would help the scientific community get out of the current taxonomic crisis, and facilitate the progress of biodiversity research.

Though similar to DNA barcoding in various aspects, the program proposed by Tautz et al. (2003) did not recommend a target sequence. Specialists were encouraged to develop and utilize markers that are appropriate for their respective groups. The possibility of using more than one sequence was discussed. The manuscript, built upon an earlier publication by the same authors (Tautz et al. 2002), was important at an earlier stage of DNA-based methods acceptance, but was practically obfuscated by the publication of Hebert et al. (2003), which is considered the main trigger of the current taxonomic revolution.
New paradigms often generate tension in the scientific community, and things have been no different with molecular taxonomy, particularly DNA barcoding. From the start, this proposal has faced original reactions from scientists, particularly systematists, generating a number of debates on morphology versus DNA. In these debates, the opinions vary from enthusiastic support to extreme negation.

\section{Morphology vs. DNA}

\section{Criticisms on the foundations and technical aspects of a DNA-based taxonomy}

The possible loss of the intellectual content of taxonomy by reducing it to a job of performing molecular identifications was one of the first reactions to the proposal of a DNA-based taxonomy (Lipscomb et al. 2003). The looming threat of seeing the study of the earths' biodiversity reduced to a technical activity in which the hypothesis testing procedure no longer has a place has haunted many taxonomists since the initial publications of Paul Hebert and collaborators. From this point on, many criticisms on DNA barcoding have followed.

What would be the real meaning of this new method? Who would use it and what are the real costs involved? Cameron et al. (2006) questioned the feasibility of molecular identifications being performed by the general public, arguing that molecular methods require laboratory procedures for tissue extraction and retention of vouchers and their complete collecting information, thus confining their use to the scientific community. Consequently, DNA-based methods would be unavailable to those who need to preserve biodiversity, being therefore useless in popularizing taxonomy. Furthermore, Cameron et al. (2006) calculated the costs of obtaining barcode sequences, and concluded that maintaining this methodology in the frontline of biological identifications would cost more than its proponents had initially envisioned. Even though the US\$ 5.00 value calculated for each sequence is not a large amount, sampling 10 individuals per species, as suggested by Hajibabaei et al. (2005), and the need to obtain even more sequences for each taxon (Meyer \& Paulay 2005), would greatly increase the predicted financial costs of barcoding. Summarizing, these two arguments advanced that DNA barcoding would neither reduce the costs of taxonomy nor make it more accessible to the general public.

Traditional taxonomists have also questioned the issue of taxon sampling (Sperling 2003, Moritz \& Cicero 2004, Meyer \& Paulay 2005). An effective environment for DNA classification would need to include a database where each taxon is optimally represented. Otherwise, species classification would be deficient (Meyer \& Paulay 2005). To account for this problem, the optimal representation in the database would have to be much larger than 10 individuals per each species (Meyer \& Paulay 2005). Limited geographical sampling, as generally performed in DNA barcoding (Hebert et al. 2003) research, has also been questioned, as it would generally fail to find species that have diverged more recently (sister-species). By focusing on populations that are genetically similar, such studies tend to overlook the still unknown diversity (Sperling 2003).

The use of DNA barcoding to delimit new species has also been a target of criticism (Cicero \& Moritz 2004, Lee 2004, Ebach \& Holdrege 2005b, Rubinoff et al. 2006). The reliability of such procedure depends on an effective distinction between intra- and interspecific variation, which is missing for several of the taxa studied, as indicated by significant juxtaposition of sequences (Meyer \& Paulay 2005, Cognato 2006, Meier et al. 2006, Whitworth et al. 2007). This issue weakens the argument that DNA barcoding can effectively achieve one of its goals, that of accelerating the discovery 
of biodiversity. The current situation of taxonomy would only be improved by the barcoding initiative if the target sequence was constant between individuals of a species and different from all other species (Prendini 2005, Meyer \& Paulay 2005, Rubinoff et al. 2006). According to DeSalle (2006), the issues commonly raised against DNA barcoding will only disappear when researchers understand that DNA is an extension (and augmentation) of taxonomy, and that it can be used only for species identification, not delimitation.

The use of molecular distances to construct the neighbor-joining trees used in DNA barcoding to place the different sequences within a taxonomic context (Hebert et al. 2004, Ward et al. 2005, Hajibabaei et al. 2006a, Borisenko et al. 2008, Kerr et al. 2009) has also been criticized (DeSalle et al. 2005, Cognato 2006). Distancebased analyses result in phenetic clusters; the latter are not indicative of common origin, and should therefore be disregarded (DeSalle et al. 2005). Furthermore, according Cognato (2006), because phenetic analyses are based on total similarity, they fail to recover information on homology and homoplasy. As a result, the evolutionary aspect of recognizing specific units is forsaken, generating unreliable identifications.

An additional criticism to molecular taxonomy worth mentioning is the lack of a well-defined species concept that can be used consistently in DNA barcoding (Rubinoff et al. 2006). The recognition of species through sequence clusters, based exclusively on percentages of molecular divergence (MOTUS, molecular taxonomic operational units) (Blaxter \& Floyd 2003, Blaxter 2004) could potentially alienate us from the natural world and its richness in form, behavior and ecology (Prendini 2005). The use of MOTUS tends to be deficient particularly because it does not provide evolutionary information about taxa, a feature that is common to other methods of analysis based on similarity (Rubinoff et al. 2006).

Technical problems with the use of a mitochondrial gene to delineate species boundaries have also been subjected to criticisms (Rubinoff et al. 2006). Certain evolutionary characteristics of the mitochondrial genome make this organelle inadequate as the only source of data for animal classification (Rubinoff et al. 2006). In fact, several authors have considered classifications based solely on a one character system as doomed to fail (Ebach \& Holdrege 2005a, DeSalle et al. 2005, DeSalle 2006). Criticisms to the exclusive use of mitochondrial genes are based on the artifacts of paraphyly or polyphyly found in more than $20 \%$ of the studies based on these genes (Funk \& Omland 2003, Meyer \& Paulay 2005). These results reflect certain aspects of the evolution of the mitochondria, which can potentially obscure the real evolutionary history of organisms (for a revision of the causes and consequences of the factors responsible for deviations from monophyly at the mitochondrial level see Funk \& Omland 2003 and Rubinoff et al. 2006).

The restrictions imposed by the very nature of the mitochondrial genome has triggered a series of criticisms to DNA barcoding on top of all other caveats already mentioned (Rubinoff 2006, Rubinoff et al. 2006). Against the DNA barcoding method, several opponents have advanced that the increased use of molecular tools can be prejudicial to alpha-taxonomy (Seberg et al. 2003, Sperling 2003, Wheeler et al. 2004, Ebach \& Holdrege 2005b); that researchers armed with DNA barcoding protocols want to engage in broad biotic studies without having to learn how to use a taxonomic key (Ebach \& Holdrege 2005b); and that they compete with traditional taxonomy for funds.

\section{DNA-based taxonomy from the point of view of its proponents}

So far we have discussed the points of view of those who have initially expressed concerns about the possible impacts of DNA barcoding on the future of morphology and biodiversity studies. We have also clarified their views regarding the use of DNA in taxonomy. From this point on, we will elaborate on the position of those who have defended the use of DNA barcoding, often as a response to the questions raised in the previous sections.

With respect to the costs involved in developing a taxonomy strongly based on DNA, Hebert \& Gregory (2005) pointed out that the expenses are only one aspect of this initiative and that they can be managed. Furthermore, the generation of a system of identification that is fast, reliable and accessible would offset the costs of implementing it. The economic benefits of excluding an exotic pest identified through barcoding, for example, would potentially pay off the costs of finding it. Another argument that invalidates these criticisms is the progressively decreasing costs of obtaining a sequence, soon to be in the 2-dollar average.

Regarding the issue of using DNA barcoding to delimit species, proponents of the method argue that the objective of this initiative is merely the clarification and delimitation of new taxa by highlighting groups that are genetically distinct (Hebert \& Gregory 2005). To them, DNA barcoding, in and of itself, will never provide sufficient information to describe a species. It can, at most, reveal genetically distinct lineages that, combined with other sources of data, will be given a Linnaean name. These researchers also point out that DNA barcoding does not guarantee complete taxonomic resolution, but it does promise proximity, giving species-level resolution in 95 to $97 \%$ of cases (Hebert et al. 2004, Ward et al. 2005), rebutting the argument that there is not a well-defined pattern of genetic distance separating species (Hebert \& Gregory 2005).

The arguments against the use of genetic distances in barcoding have been refuted based on the claim that the method does not aim to recover phylogenetic relationships, but to identify unknown species and to aid the discovery of new ones. Proponents of the method have emphasized that the place of a sequence in a distance tree, essential to its taxonomic placement, should be viewed as a hypothesis, not a fact (Hebert \& Gregory 2005). Consequently, there is no reason to reject this initial analysis of the data.

The use of MOTUs as a species concept, with a similar reach as the traditional species, was defended by Blaxter (2004). A system based on molecular operational taxonomic units, according to him, would allow fast and efficient identifications, as already obtained for organisms that are difficult to study morphologically (bacteria), including yet unknown taxa. It also facilitates research on the evolutionary patterns of diversity by providing sequence data for phylogenetic analyses (Blaxter 2004, 2006). Blaxter (2006) disagreed with the idea that the use of MOTUs lacks an evolutionary criterion and pointed out that associations between MOTUs and traditional species have been found to correspond to results obtained with phylogenies (Blaxter et al. 2005).

Gregory (2005) elaborated on some misunderstandings common to the morphology versus DNA debate, particularly with respect to DNA barcoding. He first discussed the belief that the current approach to biodiversity discovery will be replaced. He pointed out that the barcoding of life will aid in the discovery of new species, but that new taxa should not be named or described only on the basis of the target sequence. Specimens would ideally be sent to a specialist, who would study and analyze the morphology in order to name and describe the species. Species descriptions would not only involve detailed study of the voucher, but also the acquisition of high resolution images, collecting data, and other additional information. The second issue discussed by Gregory (2005) was the fear that DNA barcoding will divert funds from taxonomy. The author defended that such a threat is not real, because the method would more likely compete for funds with equivalent proposals in physics, medical and comparative 
genomics projects rather than taxonomic research (Gregory 2005, Hebert \& Gregory 2005).

The decline of alpha taxonomic research and its relationship to molecular methods was also debated (Hebert \& Gregory 2005). According to the proponents of molecular taxonomy, the use of DNA has the potential to revive taxonomy, directing new funding into the collection and cataloguing of specimens. Because it can push taxonomic research forward, molecular taxonomy is unlikely to be treated as something prejudicial. Furthermore, molecular tools have the potential to aid taxonomic investigations by helping reveal cryptic species, the identification of immature, and clarification of problems of synonymy.

Finally, the fact that many species are not mitochondrially monophyletic is not viewed as a problem by DNA barcoding proponents (consult 'BOLD systems', available at http://www. boldsystems.org/views/projectlist.php?\&, for a revision of the DNA barcoding published research). They argue that, before jumping to conclusions about mitochondrial sequence sharing between species, stronger validation of the morphology-based assignments is needed. This procedure would weed out the errors caused by bad taxonomy and resolve many incongruities between results obtained with DNA and morphology. After all, the expectation that the results obtained with DNA barcodes are consistent, accurate and un-ambiguous should be extended to other approaches (Hebert \& Gregory 2005).

In conclusion, the situation discussed above reveals the lack of agreement between researchers regarding ideas that have resurged in the past years with respect to the use of DNA in taxonomy. The objectives to barcoding, however, coincide with those of traditional taxonomy. Both are plagued with similar problems, for instance, the superposition of variation within and between species, and incomplete geographical sampling (Padial \& De La Riva 2007). Consequently, the adoption of barcoding methods by an integrative taxonomy (Dayrat 2005, Will et al. 2005) is a plausible idea. Taxonomy does not need a revolution filled with conflicts that do not contribute to the resolution of the existent crisis. It needs, instead, to evolve. The incorporation of DNA and morphological data seems an adequate solution to the existent crisis, as both sources of information, when considered alone, have several caveats (Carvalho et al. 2008).

\section{Towards Integrative Taxonomy}

Everyone knows that traditional taxonomy has serious problems that hinder it progress (May 2004). Numerous species remain unknown because of the lack of specialists in their groups. Others are only known from their original descriptions, from just the holotype, or have had their type material lost or destroyed. The amount of typematerial deposited in museums waiting for a specialist to take interest in it is unaccounted for (Padial \& De La Riva 2007). Why not, then, look for alternatives that will help develop the field of taxonomy?

Within this context, DNA barcoding cannot be viewed as a threat to taxonomy because it is able to attract interest toward biodiversity studies (Smith 2005). It is however necessary to understand that this initiative is not a panacea that will overcome all problems faced by traditional taxonomy. Even though it can be successively applied when morphology is insufficient (Herre 2006), the use of mtDNA as the only source of data in animal barcoding research is problematic and can result in the description of groups that are not monophyletic, as discussed above (Rubinoff 2006, Rubinoff et al. 2006).

In fact, one of the main objectives of this initiative, the discovery and description of new taxa, cannot be accomplished with sequence data alone (Ebach \& Holdrege 2005b). As previously mentioned, the superposition of intra- and interspecific variation is a serious problem (Meyer \& Paulay 2005, Cognato 2006, Meier et al. 2006,
Whitworth et al. 2007). This difficulty, however, is not unique to molecular data, and is encountered with other sets of data such as morphology, ecology and other sources (Will et al. 2005). The problems with the sole use of morphology in taxonomy work are also well-known (see Packer et al. 2009). Phenotypic plasticity, cryptic species and identification of immature stages are good examples (Hebert et al. 2003). From this perception that any character system used in taxonomy to the exclusion of others will fall short of the task, the practice of an integrative taxonomy that draws data from different sources is promising. This practice would certainly be superior to the current chaos generated by single data sources and illuminate taxonomic results with complementary sources of data (Will et al. 2005)

A formal proposal for an integrative taxonomy already exists (Dayrat 2005). This science aims to delimit the units of life's diversity from multiple and complementary perspectives, such as phylogeography, comparative morphology, population genetics, ecology, development, behavior etc. (Dayrat 2005). One important point of this proposal is, however, the integration of molecular and morphological data. Cryptic species are a good example of the importance of using integrated datasets whenever possible. This procedure can reveal species groups that had not been detected when a given species was initially described based on morphology alone. The use of DNA in addition to morphology helps the recognition of cryptic species that consequently become distinguished based on both sources of characters (Fisher \& Smith 2008, Wiedenbrug et al. 2009, Hamada et al. 2010).

Taxa proposed based on integrated data are better defined and better supported hypotheses for the development of other studies. Species that are ill-defined lead to incorrect answers in any discipline, which highlights the importance of that proposal. In this way, the scientific challenge for the future of taxonomy and its fundamental task is to define species in a manner that best reflects the biodiversity that exists in nature (Dayrat 2005).

The recent attention given to the practice of an integrative taxonomy originated within the context of developing integrated methodologies for research and education in biology (Wake 2003). Biology research, according to this view, should be multidisciplinary, involving different specialties from various fields, and focusing on complex problems. In this context, the technological advances of the last century such as DNA and internet should also be employed in such endeavors (Wake 2003). The call for an integrative taxonomy, therefore, has its foundations this quest to answer complex questions within biology, as a means to revive the traditional taxonomy and overcome the taxonomic impediment [based on previous arguments advanced by Wilson (1985), the CBD - Convention on Biological Diversity - has recognized the existence of a taxonomic impediment that hinders biodiversity studies and its results (La Salle et al. 2009)].

The combination of different sources of data in taxonomy is not new. One good example that dates back to as early as 2003, is Wilson's "encyclopedia of life", a database created with the goal to include information on the natural history, morphology and DNA (EOL, available at http://www.eol.org/) of every species. Lately, the value of an integrative taxonomy has been recognized by the very proponents of the barcoding of life (Smith et al. 2008, Fisher \& Smith 2008, Ward et al. 2009). Studies focusing on this point of view are available at the BOLD website (http://www.boldsystems.org/views/ projectlist.php?\&).

A successful example of incorporation of DNA barcoding in an integrative taxonomy is the Sponge Barcoding Project database (available at http://www.spongebarcoding.org/). This initiative seeks to combine morphology and DNA information to characterize the 
different species of sponges. In their website, it is possible to obtain morphological descriptions provided by taxonomists, sequences associated with the voucher, and distribution data for each species. Every entry in the site is linked to the World Porifera Database, allowing for timely updates of species names. All this information, facilitated through the internet, can be accessed from almost everywhere in the world (SBP, Sponge Barcoding Project, www. spongebarcoding.org).

In fact, incorporating molecular tools into the taxonomic work and making taxon information available on the internet are a means to make traditional taxonomy more attractive to investment funds. This practice brings taxonomy closer to the kinds of results expected today and increases its impact factor, making it more likely to compete with well-funded projects in medicine and genomics, among others.

However, criticisms to Dayrat (2005) (Valdecasas et al. 2008, Cardoso et al. 2009) cannot be ignored. Disagreements with Dayrat focus on the set guidelines he laid out to creating new names (Valdecasas et al. 2008). Another issue raised against integrative taxonomy pertains to cases when datasets (for example morphology versus DNA), disagree (Cardoso et al. 2009). The guidelines proposed by Dayrat, however, do not have to be interpreted as laws, but can be adopted by those who want some orientation when proposing new names. The focus of integrative taxonomy is the delimitation of species, not the proposition of new names (Dayrat 2005). The criticism pertaining data incongruence, on the other hand, seems unjust. Even though different sources of information are expected to agree when species boundaries are being investigated, a lack of agreement is an indication that something might be wrong with species demarcation. In such cases, the use of different sources of information is useful in pointing out the problem. When the sources of data are widely used, it is possible to solve the problem by identifying the actual number of species involved with the individuals in question (Mengual et al. 2006, Smith et al. 2008).

In conclusion, by looking at taxonomy from a less radical point of view, it is possible to see that the integration of information is an appropriate way to promote this scientific endeavor. The adoption of new technologies becomes common-place and morphology can be appreciated. In this context, it is important to support alpha taxonomy, in a manner that maintains descriptions based on morphology in equilibrium with the application of new technologies that have been advanced to overcome the taxonomic impediment (De Salle et al. 2005, Ebach \& Holdrege 2005a). The increasing number of contributions in this area is a good indication that integrative taxonomy has already been embraced.

\section{Recent contributions employing Integrative Taxonomy}

Contemporary research using integrative approaches fall into different categories:

- Testing the congruence between results obtained from various sources of data. In a sense, it centers on validating the taxonomic position of taxa (Mengual et al. 2006, Smith et al. 2008);

- Uncovering cryptic species (Schlick-Steiner et al. 2006, Roe \& Sperling 2007, Milankov et al. 2008, Vaglia et al. 2008); and

- Describing species based on more than one source of data, generally morphology and sequence data (Fisher \& Smith 2008, Mengual \& Thompson 2008).

It is important at this point to highlight the fact that the DNA barcoding community has recognized the importance of integrating data in taxonomy whenever possible. One good example is the study of Smith et al. (2008) involving parasitoid wasps (Microgastrinae) and their caterpillar hosts. They used an iterative approach, combining data on morphology, ecology and DNA barcoding. Their results led to a more detailed and comprehensive understanding of the real parasitoid biodiversity and host specificity, with better support for the morphological species and their divisions. Any data source, if analyzed in separate, would have neglected, in at least one instance, the results obtained by one of the other three, as rarely the three sources of information were completely congruent in the lineages they delineated (see Smith et al. 2008).

\section{Present Situation and Tendencies: A Conclusion}

In fact, after countless studies conducted since 2003 using DNA barcoding, criticisms and skepticism have slightly changed. The method has proven fast, reliable and cheap both in the discovery and the identification of biodiversity (Radulovici et al. 2010). The fact that DNA barcoding and taxonomy complement each other is also widely accepted by the modern scientific community, including the own proponents of the barcoding method (see Hajibabaei et al. 2007). DNA barcoding has been considered an efficient aid to traditional taxonomy, and morphology alone has also proven inefficient to solve some taxonomic problems, calling for increasing use of molecular tools (Packer et al. 2009, Radulovici et al. 2010). Researchers that initially resisted the DNA barcoding now publish in the field (CBOL Plant Working Group 2009, Seberg \& Petersen 2009).

Given that the recent studies using this method tend to be, by nature integrative (Smith et al. 2008, Wiedenbrug et al. 2009, Hamada et al. 2010), we conclude that there are no signs that barcoding is substituting traditional taxonomy, as feared at first. To the contrary, there is enough evidence that both fields are complementary (Hajibabaei et al. 2007, Radulovici et al. 2010). One factor that has probably hindered the progress of an integrated approach, however, is the amount of time involved in such research. Current professional demands, for example competition in the form of number of papers published, besides difficulties to obtain funds (particularly in undeveloped countries) make it less accessible.

At this point of our argument, it is important re-emphasize that data integration overcomes the difficulties imposed by the use of only one source of data (Mengual et al. 2006, Schlick-Steiner et al. 2006, Roe \& Sperling 2007, Milankov et al. 2008, Vaglia et al. 2008, Smith et al. 2008). One of its advantages is that new species descriptions that correspond to better supported hypotheses will facilitate future studies (Fisher \& Smith 2008, Mengual \& Thompson 2008). The importance of morphology is acknowledged and traditional morphology is revitalized by adhering to technologies that have been proposed with the taxonomic impediment in mind. In this way, the association of information to delimit species is in fact a real challenge that taxonomy has to face. Its adoption by taxonomists will contribute to a better understanding of biodiversity.

From these findings, the topic discussed throughout the paper may seem trivial, given the current acceptance of integrative taxonomy. However, even today are found articles disputing the use of both DNA barcoding and morphology in biodiversity studies (Packer et al. 2009, Ebach \& Carvalho 2010), regardless of its integrated view. A good exemple corresponds to the recent publication of Ebach \& Carvalho (2010), where DNA barcoding is discussed as being something "hostile" to taxonomic studies. According to these authors (Ebach \& Carvalho 2010: 171): "DNA barcoding does not adhere to best practice in taxonomy simply because it is not taxonomic in nature. Taxonomy, for instance, is purely morphological and not molecular". In this sense, belittling the use of molecular data in the discovery of new species, the authors also question (Ebach \& Carvalho 2010: 174): "DNA barcoding, by its own admission, is unable to completely do or replace taxonomy, how then, can it discover new species?" A question completely meaningless when viewed under the reciprocal illumination obtained by data through integrative taxonomy (DNA and morphology, among others). 


\section{Acknowledgements}

We thank CNPq for financial support and the Programa de PósGraduação em Entomologia of Universidade Federal do Paraná for the opportunity to conduct this study.

\section{References}

BLAXTER, M. \& FLOYD, R. 2003. Molecular taxonomics for biodiversity surveys: already a reality. Trends Ecol. Evol. 18:268-269.

BLAXTER, M., MANN, J., CHAPMAN, T., THOMAS, F., WHITTON, C., FLOYD, R. \& ABEBE, E. 2005. Defining operational taxonomic units using DNA barcode data. Philos. T. R. Soc. B 360:1935-1943.

BLAXTER, M.L. 2004. The promise of a DNA taxonomy. Philos. T. Roy. Soc. B 359:669-679.

BLAXTER, ML. 2006. Will DNA barcoding advance efforts to conserve biodiversity more efficiently than traditional taxonomic methods? (two views) Front. Ecol. Environ. 4:268-273.

BORISENKO, A.V., BURTON, K.L., IVANOVA, N.V., HANNER, R.H. \& HEBERT, P.D.N. 2008. DNA barcoding in surveys of small mammal communities: a field study in Suriname. Mol. Ecol. Resour. 8:471-479.

CAMERON, S., RUBINOFF, D. \& WILL, K. 2006. Who will actually use DNA barcoding and what will it cost? Syst. Biol. 55:844-847.

CARDOSO, A., SERRANO, A. \& VOGLER, A.P. 2009. Morphological and molecular variation in tiger beetles of the Cicindela hybrida complex: is an 'integrative taxonomy' possible? Mol. Ecol. 18:648-664.

CARVALHO, M.R., BOCKMANN, F.A., AMORIM, D.S. \& BRANDÃO, C.R. 2008. Systematics must embrace comparative biology and evolution, not speed and automation. Evol. Biol. 35:150-157.

CBOL PLANT WORKING GROUP. 2009. A DNA barcode for land plants. P. Natl. Acad. Sci. USA. 106:12794-12797.

CHASE, M.W. \& FAY, M.F. 2010. Barcoding of plants and fungi. Science. 325:682-683.

COGNATO, A.I. 2006. Standard percent DNA sequence difference for insects does not predict species boundaries. J. Econ. Entomol. 99:1037-1045.

CYWINSKA, A., HUNTER, F.F. \& HEBERT, P.D.N. 2006. Identifying Canadian mosquito species through DNA barcodes. Med. Vet. Entomol. 20:413-424.

DAYRAT, B. 2005. Towards integrative taxonomy. Biol. J. Linn. Soc. 85:407-415.

DESALLE, R. 2006. Species discovery versus species identification in DNA barcoding efforts: Response to Rubinoff. Conserv. Biol. 20:1545-1547.

DESALLE, R., EGAN, M.G. \& SIDDAL, M. 2005. The unholy trinity: taxonomy, species delimitation and DNA barcoding. Philos. T. R. Soc. B 360:1905-1916.

DUNN, C.P. 2003. Keeping taxonomy based in morphology. Trends. Ecol. Evol. 18:270-271.

EBACH, M.C. \& CARVALHO, M.R. 2010. Anti-intellectualism in the DNA barcoding enterprise. Zoologia 27:165-178.

EBACH, M.C. \& HOLDREGE, C. 2005a. More taxonomy, not DNA barcoding. BioScience 55:822-823.

EBACH, M.C. \& HOLDREGE, C. 2005b. DNA barcoding is no substitute for taxonomy. Nature 434:697.

FISHER, B.L. \& SMITH, M.A. 2008. A revision of Malagasy Species of Anochetus Mayr and Odontomachus Latreille (Hymenoptera: Formicidae). Plos One 3(5):e1787.

FOX, G.E., STACKEBRANDT, E., HESPEL, R.B., GIBSON, J., MANILOFF, J., DYER, T.A., WOLFE, R.S., BALCH, W.E., TANNER, R.S., MAGRUM, L.J., ZABLEN, L.B., BLAKEMORE, R., GUPTA, R., BONEN, L., LEWIS, B.J., STAHL, D.A., LUEHRSEN, K.R., CHEN, K.N. \& WOESE, C.R. 1980. The phylogeny of prokaryotes. Science 209:457-463.
FUNK, D.J. \& OMLAND, K.E. 2003. Species-level paraphyly and polyphyly: frequency, causes, and consequences, with insights from animal mitochondrial DNA. Annu. Rev. Ecol. Evol. S. 34:397-423.

GODFRAY, H.C.J. 2002. Challenges for taxonomy. Nature 417:17-18.

GREGORY, T.R. 2005. DNA barcoding does not compete with taxonomy. Nature 434:1067.

HAJIBABAEI, M., JANZEN, D.H., BURNS, J.M., HALLWACHS, W. \& HEBERT, P.D.N. 2006a. DNA barcodes distinguish species of tropical Lepidoptera. P. Natl. Acad. Sci. 103:968-971.

HAJIBABAEI, M., SINGER, G.A.C., HEBERT, P.D.N. \& HICKEY, D.A. 2007. DNA barcoding: how it complements taxonomy, molecular phylogenetics and population genetics. Trends Genet. 23:167-172.

HAJIBABAEI, M., SMITH, M.A., JANZEN, D.H., RODRIGUEZ, J.J., WHITFIELS, J.B. \& HEBERT, P.D.N. 2006b. A minimalist barcode can identify a specimen whose DNA is degraded. Mol. Ecol. Notes 6:959-964

HAJIBABAEI, M., WAARD, J.R., IVANOVA, N.V., RATSASINGHAM, S., DOOH, R.T., KIRK, S.L., MACKIE, P.M. \& HEBERT, P.D.N. 2005 Critical factors for assembling a high volume of DNA barcodes. Phylos. T. R. Soc. B 360:1959-1967.

HAMADA, N., PEPINELLI, M., MATTOS-GLÓRIA, A. \& LUZ, S.L.B. 2010. A new black fly species from Brazil, closely related to Simulium guianense Wise (Diptera, Simuliidae), revealed by morphology and DNA barcoding. Zootaxa. 2428:22-36.

HEBERT, P.D.N. \& GREGORY, T.R. 2005. The promise of DNA barcoding for taxonomy. Syst. Biol. 54:852-859.

HEBERT, P.D.N., CYWINSKA, A., BALL, S.L. \& WAARD, J.R. DE. 2003. Biological identifications through DNA barcodes. P. Roy. Soc. Lond. B 270:313-321.

HEBERT, P.D.N., STOECKLE, M.Y., ZEMLAK, T.S. \& FRANCIS, C.M. 2004. Identification of birds through DNA barcodes. Plos Biol. 2:1657-1663.

HERRE, E.A. 2006. Barcoding helps biodiversity fly. P. Natl. Acad. Sci. USA 103:3949-3950.

KERR, K.C.R., LIJTMAER, D.A., BARREIRA, A.S., HEBERT, P.D.N. \& TUBARO, P.L. 2009. Probing evolutionary patterns in neotropical birds through DNA barcodes. Plos One 4:e4379.

LA SALLE, J., WHEELER, Q., JACKWAY, P., WINTERTON, S., HOBERN, D. \& LOVELL, D. 2009. Accelerating taxonomic discovery through automated character extraction. Zootaxa. 2217:43-55.

LEE, M.S.Y. 2002. Online database could end taxonomic anarchy. Nature 417:787-788

LEE, M.S.Y. 2004. The molecularisation of taxonomy. Invertebr. Syst. 18:1-6.

LIPSCOMB, D., PLATNICK, N. \& WHEELER, Q. 2003. The intellectual content of taxonomy: a comment on DNA taxonomy. Trends Ecol. Evol. 18:65-66.

MALLET, J. \& WILLMOTT, K. 2003. Taxonomy: renaissance or tower of babel? Trends Ecol. Evol. 18:57-59.

MAY, R.M. 2004. Tomorrow's taxonomy: collecting new species in the field will remain the rate-limiting step. Philos. T. Roy. Soc. B 359:733-734.

MEIER, R., SHIYANG, K., VAIDYA, G. \& NG, P.K.L. 2006. DNA Barcoding and taxonomy in Diptera: a tale of high intraspecific variability and low identification success. Syst. Biol. 55(5):715-728.

MENGUAL, X. \& THOMPSON, F.C. 2008. A taxonomic review of the Palpada ruficeps species group, with the description of a new flower fly from Colombia (Diptera, Syrphidae). Zootaxa 1741:31-36.

MENGUAL, X., STAHLS, G., VUJIC, A. \& MARCOS-GARCIA, M.A. 2006 Integrative taxonomy of Iberian Merodon species (Diptera, Syrphidae). Zootaxa 1377:1-26.

MEYER, C.P. \& PAULAY, G. 2005. DNA barcoding: error rates based on comprehensive sampling. Plos Biol. 3:e422.

MILANKOV, V., STAHLS, G., STAMENKOVIC, J. \& VUJIC, A. 2008. Genetic diversity of Merodon aureus and M. cinereus species 
complexes (Diptera, Syrphidae): integrative taxonomy and implications for conservation priorities on the Balkan Peninsula. Conserv. Genet. 9:1125-1137.

MORITZ, C. \& CICERO, C. 2004. DNA barcoding: promise and pitfalls. Plos Biol. 2:1529-1531.

PACE, N.R. 1997. A molecular view of microbial diversity and the biosphere. Science 276:734-740.

PACKER, L., GIBBS, J., SHEFFIELD, C. \& HANNER, R. 2009. DNA barcoding and the mediocrity of morphology. Mol. Ecol. Resour. 9:42-50.

PADIAL, J.M. \& DE LA RIVA, I. 2007. Integrative taxonomists should use and produce DNA barcodes. Zootaxa 1586:67-68.

PATEL, J.B., LEONARD, D.G.B., PAN, X., MUSSER, J.M., BERGMAN, R.E. \& NACHAMKIN, I. 2000. Sequence-based identification of Mycobacterium species using the MicroSeq 500 16S rDNA bacterial identification system. J. Clin. Microbiol. 38:246-251.

PRENDINI, L. 2005. Comment on "Identifying spiders through DNA barcodes". Can. J. Zoolog. 83:481-491.

PYLE, R.L., EARLE, J.L. \& GREENE, B.D. 2008. Five new species of the damselfish genus Chromis (Perciformes: Labroidei: Pomacentridae) from deep coral reefs in the tropical western Pacific. Zootaxa. 1671:3-31.

RADULOVICI, A.E., ARCHAMBAULT, P. \& DUFRESNE, F. 2010. DNA Barcodes for Marine Biodiversity: Moving Fast Forward? Diversity 2:450-472.

RATNASINGHAM, S. \& HEBERT, P.D.N. 2007. BOLD: The Barcode of Life Data Systems. Mol. Ecol. 7:355-364.

ROE, A.D. \& SPERLING, F.A.H. 2007. Population structure and species boundary delimitation of cryptic Dioryctria moths: an integrative approach. Mol. Ecol. 16:3617-3633.

RUBINOFF, D. 2006. Utility of Mitochondrial DNA barcodes in species conservation. Conserv. Biol. 20:1026-1033.

RUBINOFF, D., CAMERON, S. \& WILL, K. 2006. A genomic perspective on the shortcomings of mitochondrial DNA for "Barcoding" identification. J. Hered. 97:581-594.

SAVOLAINEN, V., COWAN, R.S., VOGLER, A.P., RODERICK, G.K. \& LANE, R. 2005. Towards the encyclopedia of life: an introduction to DNA barcoding. Phylos. T. R. Soc. B 360:1805-1811.

SCHLICK-STEINER, B.C., STEINER, F.M., MODER, K., SEIFERT, B., SANETRA, M., DYRESON, E., STAUFFER, C. \& CHRISTIAN, E. 2006. A multidisciplinary approach reveals cryptic diversity in Western Paleartic Tetramorium ants (Hymenoptera: Formcidae). Mol. Phylogenet. Evol. 40:259-273.

SEBERG, O. \& PETERSEN, G. 2009. How Many Loci Does it Take to DNA Barcode a Crocus? Plos One. 4:e4598.

SEBERG, O., HUMPHRIES, C.J., KNAPP, S., STEVENSON, D.W., PETERSEN, G., SCHARFF, N. \& ANDERSEN, N.M. 2003. Shortcuts in systematic? A commentary on DNA-based taxonomy. Trends Ecol. Evol. 18:63-65.

SMITH, M.A., RODRIGUEZ, J.J., WHITFIELD, J.B., DEANS, A.R., JANZEN, D.H., HALLWACHS, W. \& HEBERT, P.D.N. 2008. Extreme diversity of tropical parasitoid wasps exposed by iterative integration of natural history, DNA barcoding, morphology, and collections. P. Natl. Acad. Sci. USA 105:12359-12364.

SMITH, M.A., WOOD, D.M., JANZEN, D.H., HALLWACHS, W. \& HEBERT, P.D. 2007. DNA barcodes affirm that 16 species of apparently generalist tropical parasitoid flies (Diptera, Tachinidae) are not all generalists. P. Natl. Acad. Sci. 104:4967-4972.

SMITH, V.S. 2005. DNA barcoding: perspectives from a "Partnerships for Enhancing expertise in taxonomy" (PEET) debate. Syst. Biol. 54:841-844.

SPERLING, F. 2003. DNA barcoding: Deus ex machina. Newsl. Biol. Surv. Can. 22:50-53.

SPERLING, F.A.H., ANDERSON, G.S. \& HICKEY, D.A. 1994. A DNAbased approach to the identification of insect species used for postmortem interval estimation. J. Forensic Sci. 39:418-427.

TAUTZ, D. ARCTANDER, P., MINELLI, A., THOMAS, R.H. \& VOGLER, A.P. 2003. A plea for DNA taxonomy. Trends Ecol. Evol. 18:70-74.

TAUTZ, D., ARCTANDER, P., MINELLI, A., THOMAS, R.H. \& VOGLER, A.P. 2002. DNA points the way ahead in taxonomy. Nature 418:479.

VAGLIA, T., HAXAIRE, J., KITCHING, I.J., MEUSNIER, I. \& ROUGERIE, R. 2008. Morphology and DNA barcoding reveal three cryptic species within the Xylophanes neoptolemus and loelia species-groups (Lepidoptera, Sphingidae). Zootaxa 1923:18-36.

VALDECASAS, A.G., WILLIAMS, D. \& WHEELER, Q.D. 2008. 'Integrative taxonomy' then and now: a response to Dayrat (2005). Biol. J. Linn. Soc. 93:211-216.

VOGLER, A.P \& MONAGHAN, M.T. 2007. Recent advances in DNA taxonomy. J. Zool. Syst. Evol. Res. 45(1):1-10.

WAKE, M.H. 2003. What is integrative biology? Integr. Comp. Biol. 43:239-241.

WARD, R.D., HANNER, R. \& HEBERT, P.D.N. 2009. The campaign to DNA barcode all fishes, FISH-BOL. J. Fish Biol. 74:329-356.

WARD, R.D., ZEMLAK, S.T., INNES, B.H., LAST, P.R. \& HEBERT, P.D.N. 2005. DNA barcoding Australia's fish species. Philos. T. Roy. Soc. B 360:1847-1857.

WHEELER, Q.D. 2007. Invertebrate systematics or spineless taxonomy? Zootaxa. 1668:11-18.

WHEELER, Q.D., RAVEN, P.H. \& WILSON, E.O. 2004. Taxonomy: impediment or expedient? Science 303:285.

WHITWORTH, T.L., DAWSON, R.D., MAGALON, H. \& BAUDRY, E. 2007. DNA barcoding cannot reliably identify species of the blowfly genus Protocalliphora (Diptera: Calliphoridae). P. R. Soc. B 274:1731-1739.

WIEDENBRUG, S., MENDES, H.F., PEPINELLI, M. \& TRIVINHOSTRIXINO, S. 2009. Review of the genus Onconeura Andersen et Saether (Diptera: Chironomidae), with the description of four new species from Brazil. Zootaxa 2265:1-26.

WILL, K.W., MISHLER, B.D. \& WHEELER, Q.D. 2005. The perils of DNA barcoding and the need for integrative taxonomy. Syst. Biol. 54:844-851.

WILSON, E.O. 1985. The Biological Diversity Crisis. BioScience. 35:700-706

WILSON, E.O. 2003. The encyclopedia of life. Trends Ecol. Evol. 18:77-80.

WILSON, E.O. 2004. Taxonomy as a fundamental discipline. Philos. T. Roy. Soc. B 359:739. 